\title{
IMPROVEMENT OF THE ACTIVITIES OF STATE AUTHORITIES OF UKRAINE, WHICH ARE RESPONSIBLE FOR ADAPTING NATIONAL LEGISLATION TO EU LEGISLATION IN THE FIELD OF PUBLIC SERVICE
}

\author{
Oleh Hubanov ${ }^{1}$ \\ Taras Shevchenko National University of Kyiv, Ukraine \\ Tamara Hubanova ${ }^{2}$ \\ Private Higher Educational Institute "College of Finance and Law", Ukraine \\ Olena Yara ${ }^{3}$ \\ National University of Life and Environmental Sciences of Ukraine, Ukraine
}

\begin{abstract}
The purpose of the paper is to consider content and nature of adaptation of national legislation in the field of public service to the EU legislation and specify institutional component of this process. Methodology. Methodological foundations of the research of adaptation of national legislation to the UE legislation in the field of public service are determined by a set of methods of scientific knowledge, which allow considering this problem as a multifaceted, interdisciplinary phenomenon. The research strategy, underlying the integrated approach, primarily is based on the following methodological principles: formulation of fundamental theoretical concept; development of cross-cutting concepts and categories, which ensure the unity of the approach to the object of research. Results. The article considered content and nature of adaptation of the national legislation in the field of public service to the UE legislation, as well as an institutional component of this process, it was conducted the analysis of competences of institutions that are responsible for adaptation. Practical implications. On the basis of doctrinal provisions, as well as the norms of the current legislation, the author has identified the main range of problems of national legislation adaptation in the field of public service to the EU legislation, and possible ways to improve the efficiency of authorized subjects are considered. Value/originality. It is determined that an important step in improving the efficiency of domestic institutions responsible for adaptation of national legislation to EU law in the field of public service is to strengthen cooperation with European experts on adaptation issues, especially in the terms of correct interpretation of acquis communautaire.
\end{abstract}

Key words: public service, EU legislation, national legislation, adaptation of legislation, institutions, competence.

JEL Classification: K00, K1, K3, K33

\section{Introduction}

The implementation of European integration aspirations of Ukraine requires numerical transformations in almost all spheres of life of modern Ukrainian society. At the same time, the key instrument of their planned, systematic and well-timed implementation is the subjects with the powers of authority as under the current conditions the multifaceted support for the transformational processes in the direction of Ukraine's accession to the EU is a priority task of the public authorities. In this way, defining a role for all the European integration processes is attached upon institutional component - public service.

In this context, an attention should be paid to the special significance of the problem of national legislation compliance in the field of public service with European standards, as the public service is a driving mechanism that will determine the pro-

\footnotetext{
Corresponding author:

${ }^{1}$ Faculty of Law, Taras Shevchenko National University of Kyiv.

E-mail: gubanof@ukr.net

${ }^{2}$ Private Higher Educational Institute "College of Finance and Law".

E-mail: gubanovatamara@ukr.net

${ }^{3}$ Faculty of Law, National University of Life and Environmental Sciences of Ukraine.

E-mail: Olenas.yara@gmail.com
} 
European future of our state. It is obvious that any transformations, in the direction chosen by Ukraine, are impossible or extremely complicated outside of the activities of the competent subjects acting within the proper legal framework formed in accordance with the requirements of the EU legislation. For this very reason, the problem of national legislation adaptation to the EU legislation in the field of public service becomes on the front burner to date. Within our research, an attention is focused on last but not least investigated aspect of the above-mentioned issue - the problem of improving the efficiency of domestic institutions, which are responsible for adaptation of national legislation to EU laws in the field of public service. Writing this work, we partially relied on the scientific achievements of such scholars as A. Arystarkhova, O. Yevhlevska, O. Prylypchuk, M. Smoliarova, O. Tarasov, I. Yakoviuk, and others.

The purpose of our work is to consider the content and nature of the adaptation of national legislation in the field of public service to the EU legislation and identify the institutional component of this process and then outline the main range of problems in this area and consider possible ways to increase the efficiency of the activities of authorized entities.

\section{Key concepts of national legislation adaptation to the EU legislation}

Turning to the immediate consideration of this problem, in the first place, we determine the significance of the key concepts for our study. According to the legally consolidated definition, an adaptation of legislation is a process of adjustment of the laws of Ukraine and other normative legal acts in line with acquis communautaire, that is, the legal system of the European Union (Vidomosti Verkhovnoi Rady Ukrainy, 2004).

In the legal doctrine, the notion of adaptation of the national legislation of Ukraine to the EU legislation is to be interpreted as a coherent process of approximation of its legal system, including legislation, lawmaking, legal technique, practice, law enforcement to the legal system of the European Union in accordance with the criteria put forward by the European Union to the states, which intend join it (Smoliarova).

However, more complete concept of adaptation is revealed in the process of comparative analysis with the concepts of implementation and harmonization of legislation. Thus, the content of abovementioned categories was thoroughly analysed by Tarasov O.V. supported by their use in the text of the UkraineEuropean Union Association Agreement. The scientist drew such conclusions relatively their correlation:

a) the category "adaptation", as a rather broad category, is identical or includes the following more detailed categories: "approximation", "convergence", "achievement of conformity"; b) the category "implementation" provides, in accordance with the text of the Association Agreement, "realization”, "performance", "application”, "compliance”, "introduction";

c) the category "harmonization" refers not only to national legislation but also to a wider range of corporate and technical norms, standards, methodologies, practices, etc., which directly affects the functioning of the economic system of society (Tarasov).

Guided by the above laws, the scientist argues that according to the text of the Association Agreement, implementation is always linked to the universally accepted principle of faithful fulfilment of international obligations, while adaptation may be non-legally binding from the international legal point of view. At the same time, adaptation can act, but not necessarily, as one of the ways of national-legal implementation as international legal obligations and nominally optional international standards, international "soft law", etc. As concerns harmonization, the author thinks that it also can be identified, on the basis of Association Agreement, with adaptation (Tarasov).

I. Yakoviuk, considering these concepts in the context of European integration processes, also points out that the concept "harmonization" characterizes the process of bringing the legislation in line with EU legal rules, which takes place within the European Union and is the statutory obligation solely of the member states. Adaptation, from scientist perspective, also characterizes the process of bringing the legislation in line with EU laws, but it takes place outside the European Union and applies to third countries in connection with their implementation of foreign policy course on European integration. They interpret implementation as a broad concept, as a special legislative procedure for the transformation of norms of international law into the norms of internal law (Iakoviuk, 2012).

The rectitude of these points of view is confirmed by the provisions of the Criteria for the European Integration Part of the State Target Programs, which fixes the definition of all three concepts. In particular, the adaptation of legislation (convergence) is to be interpreted as a process of bringing the laws of Ukraine and other legal acts in line with the acquis communautaire; harmonization (adjustment) - as a process of bringing national standards in line with the EU standards; implementation - as performance, realization of international legal regulations by the state (Nakaz Ministerstva ekonomiky ta z pytan yevropeiskoi intehratsii Ukrainy, 2005).

In the scientific literature, adaptation is characterized as a long, dynamic process, defined sequence of interrelated actions towards the change of the existing law and order, each link of which is logically connected with other elements that together form the program of self-development of the legal system (Ievhlevska, 2009). 


\section{Stages and institution component of the process of adapting national legislation to the EU legislation}

In accordance with the Law of Ukraine "On National Program for Adaptation of Ukraine's Legislation to EU Law", there are such stages of adapting national legislation as follows: 1) specification of the acts of acquis communautaire governing the legal relationship in the relevant field; 2) the translation of certain acts into the Ukrainian language; 3) implementation of complex comparative analysis of the regulation of legal relations in the relevant sphere in Ukraine and in the European Union; 4) the development of recommendations for adjustment of the legislation of Ukraine in line with acquis communautaire; 5) carrying out of economic, social, and political analysis of the consequences of the recommendations' implementation; 6) determination of the list of draft laws; 7) preparation of draft laws of Ukraine and other normative legal acts included in the list of draft laws and their adoption; 8) monitoring of the implementation of legislative acts of Ukraine (Vidomosti Verkhovnoi Rady Ukrainy, 2004).

A key role in the process of adapting national legislation to EU legislation in the field of public service is played by the institutional mechanism or a set of relevant institutions. In accordance with part VIII of the Law of Ukraine "On National Program for Adaptation of Ukraine's Legislation to EU Law", such institutions include the Verkhovna Rada of Ukraine, the Cabinet of Ministers of Ukraine, the authorized central executive authority in the sphere of adaptation of Ukrainian legislation to the legislation of the European Union, which is represented by the Ministry of Justice of Ukraine.

The Verkhovna Rada of Ukraine has to perform the following functions: 1) to ensure the implementation of the Program on issues that place under the competence of the Verkhovna Rada of Ukraine; 2) to consider draft laws of Ukraine developed for the Program's implementation; 3) to define the goals and tasks of the second and subsequent stages of the Program implementation, establish their time limits; 4) in case of need, to amend the Program; 5) to hear a report on the state of the Program every year; 6) to provide expert examination of the legislative proposals, submitted to the Verkhovna Rada of Ukraine by all subjects of the legislative initiative, on their compliance with acquis communautaire at all stages of the consideration of bills (Vidomosti Verkhovnoi Rady Ukrainy, 2004).

The fact should be separately emphasized that, in order to facilitate the implementation of the European integration aspirations of Ukraine, the Verkhovna Rada Committee on European Integration was formed, which was responsible for monitoring of the implementation of the National Program for Adaptation of Ukraine's Legislation to EU Law.
In order to improve the activity of the Verkhovna Rada of Ukraine relatively adaptation of the national legislation to the EU legislation, Recommendations on internal reform and capacity building for the Verkhovna Rada of Ukraine, approved by Resolution of the VRU dated March 17, 2016, No. 1035-19, consolidated a number of provisions. In particular, it is determined that:

1) in order to improve regulation of the legislative process, the Verkhovna Rada of Ukraine, in particular, the Verkhovna Rada Committee on European Integration, should develop and approve annual work plans on approximation of the legislation (in a close cooperation with the Cabinet of Ministers of Ukraine and people's deputies of Ukraine);

2) the Verkhovna Rada of Ukraine has the right to expect that all draft laws submitted by the Cabinet of Ministers of Ukraine will be accompanied by an explanatory memorandum (certificate, conclusion) regarding their compliance with the obligations under the Association Agreement;

3) the ability of the Committees of the Verkhovna Rada of Ukraine in the area of approximation of Ukrainian legislation to the European Union law should be strengthened, in particular, by establishing a responsible person for such work in each committee, taking into account the need to increase the level of cooperation between the committees of the Verkhovna Rada of Ukraine;

4) in line with the increasing capacity of Secretariat of Cabinet of Ministers of Ukraine and in order to ensure the implementation of a qualified expert examination on the compliance of the European Union law and obligations under the Association Agreement, it is necessary to strengthen the workforce capacity of the Verkhovna Rada of Ukraine, as well as the Secretariat of the Verkhovna Rada Committee on European Integration. Relevant employees should be provided with the opportunity to familiarize themselves with the best practices of the European Union and exchange of advanced practices in this area (working out draft laws, implementation and monitoring of the realization of approximated legislation, and the legislation weaknesses assessment).

The next institution that is responsible for adapting national legislation to the EU legislation is the Cabinet of Ministers of Ukraine, which performs the following tasks in this area: 1) ensures the Program's implementation, except matters related to the competence of the Verkhovna Rada of Ukraine; 2) approves, after approbation by Committee of the Verkhovna Rada of Ukraine on European Integration, an annual plan of measures for the Program implementation; 3 ) annually provides expenditures for the Program implementation measures in the projects of the State Budget of Ukraine (Vidomosti Verkhovnoi Rady Ukrainy, 2004).

As a part of Secretariat of the Cabinet of Ministers of Ukraine, the Bureau of European Integration was 
formed, the main tasks of which are organizational, expert-analytical, informational, and other support for maintenance of the activities of the Cabinet of Ministers of Ukraine, Government Committees, the Prime Minister of Ukraine, the First Vice Prime Minister and Vice Prime Ministers, Minister of the Cabinet of Ministers of Ukraine and his deputies on issues of coordination, continuity and consistency of implementation of state policy, including on approximation of Ukrainian legislation to the EU legislation (Polozhennia pro Biuro yevropeiskoi intehratsii Sekretariatu Kabinetu Ministriv Ukrainy).

The Ministry of Justice of Ukraine acting as the authorized central executive body in the sphere of adaptation of Ukrainian legislation to the legislation of the European Union: 1) annually submits proposals, in due order, on measures financing for the Program implementation to take them into consideration in the draft of State Budget of Ukraine to the Ministry of Finance of Ukraine; 2) together with Committee of the Verkhovna Rada of Ukraine on European Integration, monitors the Program implementation; 3) ensures implementation of the policy in the field of Ukrainian legislation adaptation to the legislation of the European Union; 4) performs scientific-expert, analytical, information and methodological support for the Program implementation, translation of acts of acquis communautaire into Ukrainian, and the preparation of a glossary of the terms of the acquis communautaire (Vidomosti Verkhovnoi Rady Ukrainy, 2004).

In addition, accordingly to the Resolution of the CMU dated October 15, 2004 No 1365, the Coordination Council for the Adaptation of the Ukrainian Legislation to the Legislation of the European Union was established for the purpose of ensuring interaction between public authorities and non-state institutions during the implementation of the National Program for Adaptation of Ukraine's Legislation to the EU law. The main task of the Coordination Council under the provisions approved by the specified resolution as follows: 1) proposals elaboration on cooperation development with the EU in the adaptation of Ukrainian legislation to the European Union one; 2) the formation of common approaches to the implementation of activities on adaptation of Ukrainian legislation to the legislation of the European Union; 3) determination of the list of executive bodies that are responsible for the organization of work on the adaptation of Ukrainian legislation to the legislation of the European Union; 4) preparation of the annual plan of measures for the implementation of the National Program for Adaptation of Ukraine's Legislation to the EU law; 5) consideration of the state of implementation of the measures plan for the execution of the National Program for Adaptation of Ukraine's Legislation to the EU law; 6) preparation and submission of annual report on the state of Program implementation to the Verkhovna Rada of Ukraine (Postanova Kabinetu Ministriv Ukrainy, 2013).
However, the abovementioned bodies are not the only institutions, which are responsible for adaptation of the national legislation to the EU legislation. Thus, sector ministries and other executive bodies implement the tasks of adapting legislation within their competence. Some agencies and institutions also perform specific tasks, such as the National Agency of Ukraine on Civil Service and the National Academy for Public Administration under the President of Ukraine, responsible for training, retraining and advanced training of specialists in the field of European and Euro-Atlantic integration (Adaptation of Ukrainian legislation to the EU laws).

According to the CMU Resolution dated June 4, 2008, No. 528, it was created an institution with special competence in the sphere of adaptation of the national legislation to the EU laws in the field of public service - the Centre for Adaptation of the Civil Service to the Standards of the European Union (previously called "Centre for Support of Civil Service Institutional Development”).

The main tasks of the Centre are: 1) participation in the preparation of proposals on the formation of public policy and regulatory activities in the field of civil service and public administration, their adaptation to the EU standards, conduct of administrative reform and development of state institutions in the context of European integration of Ukraine, the use of institutional instruments in Ukraine; 2) scientific, expert, information-analytical, methodological, organizational, and other provision of preparation and implementation of programs and activities in the specified field; 3 ) improving existing and promoting the introduction of new standards and procedures for the work of civil servants and local self-government officials, the activities of state authorities and local selfgovernment bodies on the basis of best international practice; 4) participation in the implementation of modern information technologies in the work of state authorities and local self-government bodies; 5) advisory support of public authorities and local selfgovernment bodies, dissemination of legal, scientific and other information on the civil service and public administration, their adaptation to the EU standards, administrative reform and development of state institutions in the context of European integration of Ukraine, in particular, the use of institutional instruments in Ukraine; 6) participation in the implementation of cooperation between Ukraine and the EU, consulting and methodological support and monitoring within the limits of its powers of executive authorities activity in fulfilment of obligations assumed by Ukraine to the EU and international organizations; 7) assistance to the National Agency of Ukraine on Civil Service in fulfilling its tasks and functions regarding the use of institutional instruments in Ukraine (Postanova Kabinetu Ministriv Ukrainy, 2008). 


\section{Conclusions}

Clarified the essence and content of the process of adaptation of the national legislation to the EU legislation, as well as the list and institutions' competence dealt with this problem, we will turn to the identification of the directions of increasing the efficiency of their activities. First of all, we think it is necessary to emphasize the most problematic aspects of adaptation of Ukrainian legislation to the EU legislation in the field of public service in order to determine in the future ways of their solution, which will allow increasing the efficiency of the activities of mentioned institutions.

Forexample,PrylypchukO.V., whohascomprehensively analysed the problematic aspects of the problem under study, offers the following measures to resolve the existing problems related to the adaptation of the national legislation to the EU legislation: a) creation of one integral system of Ukrainian legislation (combination of the adaptation process with the adoption of new regulatory legal acts to fill the gaps in the current legislation); b) the development by the state authorities of "harmonograms" in Ukraine - schedules of legislation harmonization for certain branches of law; c) active involvement of foreign experts and maximum use of the EU technical assistance in adapting Ukrainian legislation (Prylypchuk, 2015); d) publications guarantee of the permanent reports of each responsible authority on the state of assistance in the implementation of the Ukrainian legislation approximation to the EU legislation; e) establishment of an effective mechanism for the proper consideration of the recommendations of the EU institutions in order to stop the practice of ignoring them or "blind execution" (Prylypchuk, 2016).

In addition, the legislation in the field of public service, as any national legislation in the whole, is characterized by a large number of contradictions, gaps, and collisions, which greatly complicated the process of its adaptation. If in most European countries, at the stage of their aspiration for EU membership, this process took about seven years, but in Ukraine this figure is twenty years, if counting from the moment of the chronological adoption of the first normative act in this sphere Resolution of the Cabinet of Ministers of Ukraine dated June 12, 1998 No 852 "On Launching the Mechanism of Ukrainian Laws Adaptation to the EU Norms" (Postanova Kabinetu Ministriv Ukrainy, 1998). The above mentioned points out the necessity for systematic and meticulous work on the analysis and improvement of the existing legislation in the field of public service before the comparative analysis of the acts of the national legislation and the EU laws and adjustment them in line with each other. The existing problem is also complicated by the fact that Ukrainian legislation in the field of public service is unified. The unsystematic nature of its structure, the collision of content as well as the presence of gaps combined with the unsettled process of rulemaking complicates adaptation of national legislation to the EU legislation, therefore, at the present stage, the responsible institutions for adaptation are required a simultaneous, integrated solution to a wide range of tasks, not only connected with the adaptation of national legislation to EU legislation, but also with the improvement of its content, legal technique, elimination of gaps, and systematization.

An important step in improving the effectiveness of domestic institutions which are responsible for adaptation of the national legislation to EU laws in the field of public service is also the strengthening of cooperation with European experts on adaptation, especially in terms of the correct interpretation of acquis communautaire.

However, the most urgent problem that requires an urgent solution is defined in the Resolution of the Verkhovna Rada of Ukraine dated March 17, 2016 No. 1035-19 "On Measures Implementation of Recommendations on Internal Reform and Increasing Institutional Capacity of the Verkhovna Rada of Ukraine": it is necessary to adopt a new law on the implementation of the Association Agreement and introduction of law rules of the European Union instead of the obsolete Law of Ukraine "On National Program for Adaptation of Ukraine's Legislation to EU Law". The transformation in the direction of statutory regulation of the adaptation process of Ukrainian legislation to the EU legislation, as well as the process of rule-making in general, should be a significant shift that will promote the efficiency improvement of the activities of the above-mentioned institutions.

\section{References:}

Vidomosti Verkhovnoi Rady Ukrainy (2004) Pro Zahalnoderzhavnu prohramu adaptatsii zakonodavstva Ukrainy do zakonodavstva Yevropeiskoho Soiuzu : Zakon Ukrainy vid 01.10.2011 № 1629-15 [On National Program for Adaptation of Ukraine's Legislation to EU Law: the Law of Ukraine dated 01.10.2011 No 1629-15]. Vidomosti Verkhovnoi Rady Ukrainy, no. 29, Art. 367.

Smoliarova, M.L. Poniattia ta zmist adaptatsii zakonodavstva pro pratsiu Ukrainy do zakonodavstva Yevropeiskoho Soiuzu [The concept and content of the adaptation of the labour legislation of Ukraine to the legislation of the European Union]. Retrieved from: www.nbuv.gov.ua/

Tarasov, O.V. Adaptatsiia, implementatsiia chy harmonizatsiia prava YeS? [Is it adaptation, implementation or harmonization of the EU law?]. Retrived from: http://dspace.nulau.edu.ua/

Iakoviuk, I. (2012) Adaptatsiia i harmonizatsiia zakonodavstva v umovakh intehratsii: problema spivvidnoshennia [Adaptation and harmonization of legislation in terms of integration: the problem of correlation]. Visnyk Akademii pravovykh nauk Ukrainy, no. 4, pp. 29-42. 
Pro zatverdzhennia Metodyky vyznachennia kryteriiv yevrointehratsiinoi skladovoi derzhavnykh tsilovykh prohram : Nakaz Ministerstva ekonomiky ta z pytan yevropeiskoi intehratsii Ukrainy vid 16.03.2005 № 62 On Approval of Criteria for the European Integration Part of the State Target Programs: the Order of the Ministry of Economy and European Integration of Ukraine dated 16.03.2005 No 62]. Retrieved from: http://zakon5.rada.gov.ua/laws/show/z0438-05

Ievhlevska, O.L. (2009) Adaptatsiia zakonodavstva yak umova maibutnoho chlenstva Ukrainy v Yevropeiskomu Soiuzi [Adaptation of legislation as a condition for Ukraine's future membership in the European Union]. Derzhavne budivnytstvo ta mistseve samovriaduvannia : zb. nauk. pr., Kharkiv: Pravo, pp. 118-129.

Pro zakhody $\mathrm{z}$ realizatsii rekomendatsii shchodo vnutrishnoi reformy ta pidvyshchennia instytutsiinoi spromozhnosti Verkhovnoi Rady Ukrainy: postanova Verkhovnoi Rady Ukrainy vid 17.03.2016 № 1035-VIII [On Measures Implementation of Recommendations on Internal Reform and Increasing Institutional Capacity of the Verkhovna Rada of Ukraine: the Resolution of the Verkhovna Rada of Ukraine dated 17.03.2016 No 1035-VIII]. Retrieved from: http://zakon3.rada.gov.ua/laws/show/1035-19

Polozhennia pro Biuro yevropeiskoi intehratsii Sekretariatu Kabinetu Ministriv Ukrainy: Dokument yevropeiskoi intehratsii [The Regulation on the Bureau of European Integration of the Secretariat of Cabinet of Ministers of Ukraine: European Integration Document]. Retrieved from: http://www.kmu.gov.ua

Deiaki pytannia adaptatsii zakonodavstva Ukrainy do zakonodavstva Yevropeiskoho Soiuzu : postanova Kabinetu Ministriv Ukrainy vid 16.03.2013 № 1365-2004-p [Some Issues of Adaptation of Ukrainian Legislation to the EU Laws: the Resolution of the Cabinet of Ministers of Ukraine dated March 16, 2013 No 1365-2004-ח]. Retrieved from: http://zakon3.rada.gov.ua/laws/show/1365-2004-\%D0\%BF\#n79

Adaptatsiia zakonodavstva Ukrainy do zakonodavstva YeS: stattia [Adaptation of Ukrainian legislation to the EU laws: an article]. Retrieved from: http://shev.gov.ua/

Pytannia Tsentru spryiannia instytutsiinomu rozvytku derzhavnoi sluzhby: postanova Kabinetu Ministriv Ukrainy vid 04.06.2008 № 528 [On Issue of Center for Support of Civil Service Institutional Development: the Resolution of the Cabinet of ministers of Ukraine dated 04.06.2008 No 528]. Retrieved from: http://zakon1.rada.gov.ua/ laws/show/528-2008-\%D0\%BF

Prylypchuk, O.V. (2015) Problemy adaptatsii zakonodavstva Ukrainy do zakonodavstva YeS [Problems of adaptation of Ukrainian legislation to the EU legislation]. Derzhavne budivnytstvo, no. 1. Retrieved from: http://www.kbuapa.kharkov.ua/

Prylypchuk, O.V. (2016) Realizatsiia adaptatsii zakonodavstva Ukrainy do zakonodavstva YeS: normatyvnopravove ta orhanizatsiine zabezpechennia [Implementation of adaptation of Ukrainian legislation to EU legislation: legal and organizational provision]. Teoriia ta praktyka derzhavnoho upravlinnia, no. 3 (54). Retrieved from: http://www.kbuapa.kharkov.ua/

Pro zaprovadzhennia mekhanizmu adaptatsii zakonodavstva Ukrainy do zakonodavstva Yevropeiskoho Soiuzu : postanova Kabinetu Ministriv Ukrainy vid 12.06.1998 № 852 [On Introduction of the Mechanism of Adaptation of the Legislation of Ukraine to the Legislation of the European Union: Resolution of the Cabinet of Ministers of Ukraine dated 12.06.1998 No 852]. Retrieved from: http://zakon2.rada.gov.ua/laws/show/852-98-\%D0\%BF 